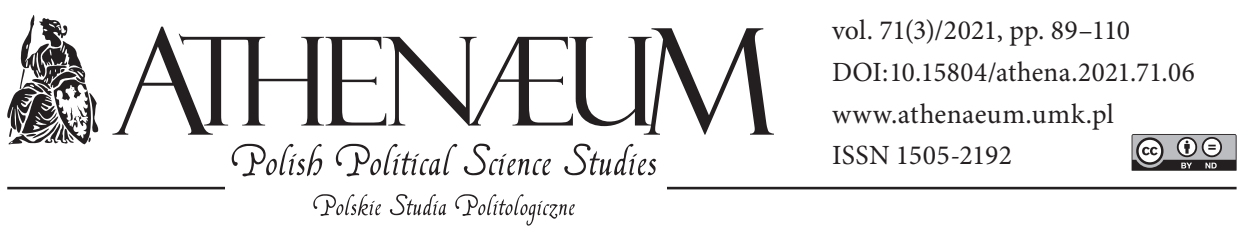

\title{
CONTEMPORARY FAMILY POLICY IN SOUTH KOREA: TOWARDS THE INCREASE OF FERTILITY
}

\author{
WSPÓŁCZESNA POLITYKA RODZINNA W KOREI \\ POŁUDNIOWEJ. W KIERUNKU WZROSTU DZIETNOŚCI
}

Katarzyna Juszczyk-Frelkiewicz* •

\begin{abstract}
The paper focuses on the assessment of how effective the Korean government's actions taken to increase the fertility rate are. South Korea is a country with a very low fertility rate which is below the replacement level. This demographic situation causes the ageing of the Korean population. The paper shows the contemporary family policy, the analysis of sociodemographic indicators and the analysis based on the data from the Korean Longitudinal Survey of Women and Families in the two periods of time: in 2007 and 2018, in order to show changes in the fertility intentions among the Korean women - in the sociological perspective. The statistical analysis indicates that the majority of the respondents had no intentions of having children. The results indicate that the Korean government's actions are not sufficient to create an environment supporting the family in fertility intentions and
\end{abstract}


behaviour, which is reflected in the continued low fertility rate.

Keywords: family policy; fertility; family; women; South Korea znajduje odzwierciedlenie w utrzymującym się na niskim poziomie współczynniku dzietności.

Słowa kluczowe: polityka rodzinna; dzietność; rodzina, kobiety; Korea Południowa

\section{THE FERTILITY PROBLEM IN SOUTH KOREA - GENERAL CHARACTERISTICS}

South Korea is a country which faces social problems such as low fertility (J. Yoon, 2006; Yoo \& Sobotka, 2018; Jung et al., 2019; S. Lim, 2021) and ageing population (D.H. Lim, Ryu, \& Jang, 2020), which is typical of the emerging society 5.0 in that country as well as in Japan (cf. $5^{\text {th }}$ Science and Technology Basic Plan, n.d.). The analysis of the demographic data of over 60 years (O'Neill, 2021) shows that South Korea has been undergoing dramatic demographic changes in the fertility rate, the number of population and the structure of the society. Till 1945, fertility in Korea was stable and was on the high level (6.0). In the period from 1945 till 1950 a decrease was observed from 6.0 to 5.2, in the aftermath of the war. Then, it increased above 6.3 in the $1950^{\text {s }}$ due to the devastation and mass-displacement caused by the Korean War. As stability returned to the region, South Korea's fertility rate fell sharply throughout the remainder of the century, as modernization, urbanization, and the implementation of family planning programs would see fertility fall to 2.6 in 1983 so from that time South Korea could be described as a low birth rate society. By 1990 fertility fell just over 1.5 children per woman (O’Neill, 2021). Moreover, since 2001 South Korea has been an ultra-low birth rate society (TFR 1.31). The first lowest point of fertility rate was in 2005 - 1.09, after that fertility slightly increased and in 2016 the Total Fertility Rate was 1.17 (Statistics Korea, 2016), but this slight increase took only two years, because in 2018 South Korea experienced the lowest fertility rate ever -0.92 (Statistics Korea, 2020). Low fertility causes fast ageing of the Korean society (D.S. Kim, 2005; The World Bank, n.d.). Today's fertility rates strongly influence the size of the future labour force, for instance, with knock-on effects on future economic performance, tax revenue and the sustainability of the social protection systems. Ageing society is a huge social problem and a challenge for the Korean government to create a family policy that will contribute to the natural increase. 


\section{METHODOLOGY}

Due to the persistently low level of fertility in Korea, which is brought about by demographic, social and economic problems, the research problem is extremely important. It will allow assessing to what extent the creation of the family policy and actions taken by policymakers are effective, i.e., they aim at increasing child births. The article presents analysis of sociodemographic and economic indicators that directly or indirectly affect fertility and also comparative statistical analysis of fertility intentions of Korean women according to the data from the Korean Longitudinal Survey of Women and Families (KLoWF) from 2007 and 2018, showing changes over time and current trends in fertility intentions.

The aim of the research is the assessment of how effective the contemporary family policy in South Korea is. The research question was: Is the contemporary policy effective enough, i.e., does it affect the fertility rate?

The effectiveness of the actions taken is measured in two stages. On the one hand, the following elements will be analysed: fertility rate across time, number of children, percentage of mothers and fathers taking leave due to child delivery - this analysis forms stage 1 of the analysis in this article. On the other hand, the following elements will be analysed: number of children and fertility intentions of Korean women according to the data from the Korean Longitudinal Survey of Women and Families (KLoWF) from 2007 and 2018 - this analysis forms stage 2.

The presentation of the actions and law regulations taken by the government under the family policy was the background of the analysis - cf. chapter: Contemporary family policy.

The study covered data from two surveys as to conduct a comparative analysis. KLoWF is a longitudinal survey conducted by the Korean Women's Development Institute (certificate number KNSO: 33801). The multistage scheme for selecting the sample was used for the stratification of the sample of women that was representative for the country from among 9084 households from all urban and rural districts in Korea, except for the island of Jeju. The population covered by the survey consists of the total of 10,013 adult women aged 19-64 (the percentage of responses: $95.8 \%$ ), which took a survey every two years starting from 2007 (the exception is a survey carried out in 2008). The questionnaires were carried out by trained pollsters who conducted direct interviews via the Computer-Assisted Personal Interviewing (CAPI). Further information on the project and methodology was published by the Korean Women's Development Institute (Park et al., 2008). 
The second part of the analysis presents the aspects of the number of children and fertility intentions among the Korean women (respondents of KLoWF), which are dependent variables. The dependent variables were analysed in correlation with the independent variable of the respondents' age groups. The fertility intentions among the Korean women were compared in terms of changes over time between the first (2007) and the seventh wave (2018) of the surveys.

The statistical analysis adopted the categorisation of women in their reproductive age - between 19 and 45, thereby the 19-49 age group adopted by the World Health Organization (2006) was not chosen due to very rare cases of women aged 46-49 willing to have children.

The statistical analysis of the research material collected as part of the Korean Longitudinal Survey of Women and Families was carried out with the aid of the statistical programme SPSS.

The statistical analysis used the independence test of $X 2$ (chi-square) in order to test the relationship between the respondents' age group, number of children and fertility intentions among the Korean women.

\section{CONTEMPORARY FAMILY POLICY}

The article focuses on the family policy, so it is necessary to define the term. Family policy has been a centre of interest among researchers around the world for many decades (Gauthier, 1996; Saraceno, 2011; Mätzke \& Ostner, 2010; Hank \& Steinbach, 2019). The definition of family policy proposed by Adem (2012) and Bogenschneider (2014) describes family policy as a type of public and social policy aimed at promoting, protecting and strengthening families across five domains of family functioning: family creation, economic support, partnership support, childrearing, and caregiving. Examples of family policies include services and financial supports for child care, parental and family leave, child benefits and allowances, regulations related to marriage, cohabitation, and also domestic violence. Although a range of social and economic policies affect families, the proposed definition of family policy does not include indirect effects, such as healthcare, housing and employment policies.

Goals and instruments of family policies differ over time and across countries (Gauthier, 1996). Governments of countries are trying to create a family policy that is adapted to the changing social, political and economic situation, as well as to the related social problems and phenomena. 
For years, South Korea's family policy has enjoyed interest in particular among Korean researchers, who present the evolution of the family policy (D. Lee, 2018), its development and challenges (Chin et al., 2012), comparing the family policy expansion with other countries such as Japan (Fleckenstein \& S.Ch. Lee, 2017) and focusing on the issue how family policies can reconcile fertility and women's employment (S. Lee, Duvander, \& Zarit, 2016).

The family policy in South Korea was analysed by D. Lee (2018), who presented the trajectory of the family policy development in South Korea from the $1940^{\mathrm{s}}$ to the present. The author analysed the background of the policy instruments, the policy instruments and the policy goals. She differentiated three periods of development of the family policy in Korea. The first period was from 1945 to 1988 - it was an era of embryonic Korean family policy when family intervention was limited and indirect, based on Confucian familism. During the second period, from 1988 to 2003, explicit family policies emerged, but the Korean government kept family intervention to a minimum - it maintained a division of roles between the state, the market and families (the state as the regulator and the market/families as the providers), and maintained patriarchal family relations and gendered family roles based on Confucian familism. The third period, from 2003 to 2016, showed an explosive expansion of family policies and changes in policy goals and regimes based on neo-familism, which emphasizes democratic and equal gender relations within families and a family-friendly, supportive society.

Writing about contemporary family policy, it is important to mention what contributed to the drastic fall in Korean fertility after 1960. In the 1960s, the total fertility rate in South Korea was around 6.0 (D.S. Kim, 2005), therefore the policymakers decided to introduce the anti-natalist policy in 1962 (Population Growth Control Policy 1962-1970), which aimed to reduce the average number of children the Koreans had, exerted a huge influence on the decrease in the number of births. Since then, the idea of a marriage with one or two children has become very popular, which made the total fertility rate drop below the replacement level (2.1) in 1983 and continue declining. The start of the efforts to increase the number of births in Korea took place in 1996, when the government abolished the fertility control policies and adopted a New Population Policy (Cho, 2006, p. 3; S.S. Lee, 2009). The designed and implemented family policy was an intervention of the consequences of the anti-natalist policy of 1962. The main goal of the family policy was to increase the birth rate.

In 2004, the government established the Presidential Committee on Aging and Future Society, which provided the government's support for free deliv- 
ery, incentives to encourage births, and tax favours for nursing and education expenses as parts of the birth encouragement policy. In addition, the government enacted the Basic Act for Low Fertility and Ageing Society in 2005 to establish the systematic foundation for low fertility (S.S. Lee, 2009, p. 63).

In the period of 2006-2010, the government established the "Saero Maji" plan, i.e., Short-Term Plan and the First Basic Plan for Low Fertility and Aged Society (Ministry of Health and Welfare, 2015). In the following years, from 2011 to 2015, the Second Plan for Low Fertility and Aged Society (Ministry of Health and Welfare, 2015) and from 2016 to 2020 - the Third Plan for Low Fertility and Aged Society were implemented. Each of the introduced pro-natalist policies was adapted to the conditions as well as the existing social and demographic problems (S.S. Lee, 2009, p. 63).

Korea's contemporary family policy includes gender equality policies. They are designed in many ways with a strong emphasis on work-life balance policies for sustainable economic growth and also aspects on gender equality. They highlight issues related to supporting the father's greater involvement in childcare, facilitating women's entry into the labour market, increasing available jobs for women, and supporting women in pursuing a career.

When analysing the contemporary family policy and gender equality, it can be seen that these policies are very well designed because of the spheres of life in which the most problems exist (especially for the female gender). These policies focus on compatibility of work and family and creating opportunities for parents to spend more time with their children and family. They provide childcare service and support for multicultural families. They also focus on maternity, child, infant and pre-schoolers services. They also aim at reducing the gender gap and worklife balance and focus on the utilisation of women's resources (cf. Ministry of Gender Equity and Family; Ministry of Health and Welfare).

The part of the family policy are also maternity, paternity and parental leaves (Ministry of Health and Welfare, 2015). Maternity leave is 90 calendar days a minimum of 45 days must be taken after birth. It provides $100 \%$ of ordinary earnings at the time of taking leave paid by the employer for the first 60 days, and $100 \%$ of ordinary earnings paid by the Employment Insurance Fund for the last 30 days (H. Kim, 2017a, p. 1). In 2020, the upper limit on the maternity benefit for the last 30 days increased from 1.800.000 KRW (about 1.300 EURO) to 2.000.000 KRW (about 1.400 EURO). This means that the total maternity leave benefit paid for 90 days by Employment Insurance Fund increased to 6.000.000 KRW (about 4.450 EURO). 
Paternity leave in Korea is becoming more and more popular - till September 2019 it was a period of three to five days. It provided 100\% of ordinary earnings for the first three days paid by the employer. The remaining two days were unpaid (H. Kim, 2017b, p. 253). From October 2019, the duration of the paternity leave was extended from three to five days up to ten days, paid by the employer. The Employment Insurance Fund pays for five days of leave up to the monthly limit of KRW 2.000.000 (about 1.400 EURO) (H. Kim \& Shin, 2021, p. 370).

The Ministry of Employment and Labour offers the longest 52-week paid parental and home care leave reserved for fathers as compared to the OECD countries (OECD, 2017). According to the statistics (Statista, 2018), in 2008, only 355 fathers took such a long leave. In turn, in 2017, over 12,000 fathers took paid parental and home care leave (Statista, 2018). There is an upward trend in the number of men using paid parental and home care leave, and thus there is a downward trend among women.

Parental leave is a period of one year for each employed parent. Both parents can take leave at the same time, subject to the agreement of both employers. If both parents take leave at the same time, only one parent receives the parental leave benefit of $40 \%$ of ordinary earnings. This rises to $60 \%$ of ordinary earnings for parents taking part-time parental leave. In cases where both parents take parental leave for the same child at different times, the allowance for the first three months of leave taken by the second parent increases to $100 \%$ of ordinary earnings (H. Kim, 2017a, pp. 1-2).

Another government activity was the Best Family-Friendly Management programme, in which the government certifies the most family-friendly companies that promote a good work-life balance among their employees, including proper implementation of leave entitlements and flexible workplace arrangements (H.J. Kim, 2015). This solution should ensure that working fathers and mothers can spend more time with their families.

The government has also launched two campaigns - Family Day and Father's Month - to better facilitate the adoption of family-friendly management. Every Wednesday is a Family Day in order to encourage the overworked Koreans to finish work on time at least one day a week so that they can spend time with their families. In addition, every last Wednesday is now the Culture Day. In that day families can get discounts and free admissions to theatres, shows and exhibitions (H.J. Kim, 2015).

Yet another action that the government has introduced is the customised child care in day care centres, in which full-time moms can leave their children 
for free from 9 a.m. to 3 p.m., and children of working moms from 7 a.m. to 7 p.m. (Poon, 2018). In Korea, the work culture dominates, professional work takes up most of the time thus taking away the time devoted to the family. This solution should ensure that working fathers and mothers can spend more time with their families.

The Ministry of Health and Welfare introduced a new regulation of the financial support to pregnant and child raising women as part of the family policy, which did not exist several years ago. The financial support is provided as vouchers for children at different age groups without having to comply with income conditions. The monthly childcare service voucher differs according to the age category of the child: from 0 to 1 year of age $-825.000 \mathrm{KRW}$ (about 600 EURO), from 1 to 2 years of age - 569.000 KRW (about 400 EURO), from 2 to 3 years of age $-438.000 \mathrm{KRW}$ (about $300 \mathrm{EURO}$ ), and from 3 to 5 years of age $220.000 \mathrm{KRW}$ (about $160 \mathrm{EURO}$ ). There are also medical allowances to mothers and their new born children for healthcare bills related to maternity. Pregnant women are able to get e-vouchers of $500.000 \mathrm{KRW}$ (about $400 \mathrm{EURO}$ ) that can be used to pay medical bills related to pregnancy. There also exists a monthly childcare service voucher to reduce the financial burden associated with parenthood, and maintain a desirable work-life balance. Additionally, families with children aged $0-5$, excluding the wealthiest $10 \%$, will be eligible for a child benefit of 100.000 KRW (about 70 EURO) per month (from September 2018) (Ministry of Health and Welfare).

The latest information indicates that under the new policy, the government will provide $300.000 \mathrm{KRW}$ (about $220 \mathrm{EURO}$ ) as a bonus every month to all infants in the first year after their birth starting from 2022, while the monthly cash allowance will have gradually expanded to $500.000 \mathrm{KRW}$ (about 370 EURO) by 2025. The new incentives and cash bonuses are separate from the government's earlier monthly allowance of $100.000 \mathrm{KRW}$ (about $70 \mathrm{EURO}$ ) for each child under the age of 5 . Also, the government will dole out a 2 million won (about 1,500 EURO) cash bonus to expectant parents to help cover their prenatal expenses starting from 2022. The government also plans to increase the current $600.000 \mathrm{KRW}$ (about $450 \mathrm{EURO}$ ) congratulatory allowance for each pregnant woman to 1 million won (about 750 EURO), while also including extra perks for working parents. Under the new package, couples with a child less than 12 months old can each receive up to 3 million won (about 2,200 EURO) in a monthly salary when both take a 3-month leave from work. Due to the high education expenses, the government will also provide university tuition fees to 
families in the low-income bracket with more than three children (Ministry of Health and Welfare).

In general, in Korea, tradition defines a man as the head of a family who must meet the economic needs of the family members. To meet tradition and stereotypical thinking, the government is trying to change the image of a man. Actions are taken to make the image of a man become popular not only as the head of the family but also as an active father who participates in the family life - takes care of children and takes part in their upbringing.

\section{ANALYSIS PART 1 - ANALYSIS OF SOCIODEMOGRAPHIC INDICATORS}

This part of the analysis will present sociodemographic and economic indicators that directly or indirectly affect fertility, the analysis of which will provide a close assessment of how effective the actions taken by the Korean government are in order to cause fertility growth.

South Korea is a country where $98 \%$ of children are born in a marriage union. Births of children outside marriage are rare - only $2 \%$ of children are born this way. Since 1995, the proportion of extramarital births has not changed significantly (OECD, 2017). Since the introduction of the anti-natalist policy in South Korea in 1962 aimed at reducing fertility, which at the time was high with the total fertility rate of 6.0 (D.S. Kim, 2005), there has been a rapid and systematic decrease in the number of births of children up to the 1990s. In later years, this decrease was milder (see Graphs 1 and 2).

The decrease in the number of married couples is directly linked to low fertility. Since 1980, there has been a steady decline with minor fluctuations. In 1980, the crude marriage rate was $10.6 \%$ and in 2020 it was $4.2 \%$ (see Graph 3).

The average age of women and men getting married also increased - in 2020, for women it was around 31 years of age, and for men around 33 years of age (see Graph 4). The increased average age for getting married has an effect on the age people become parents. In 2019, most children were born in age groups between 30 and 34 and between 35 and 39 (Statistics Korea, 2020b).

Indirectly, fertility is also affected by women's professional activity, which shows an upward trend (although slowly). In 2000, the labour force participation of women was $48.8 \%$. In 2020, it increased to $52.8 \%$. However, there is still a very 

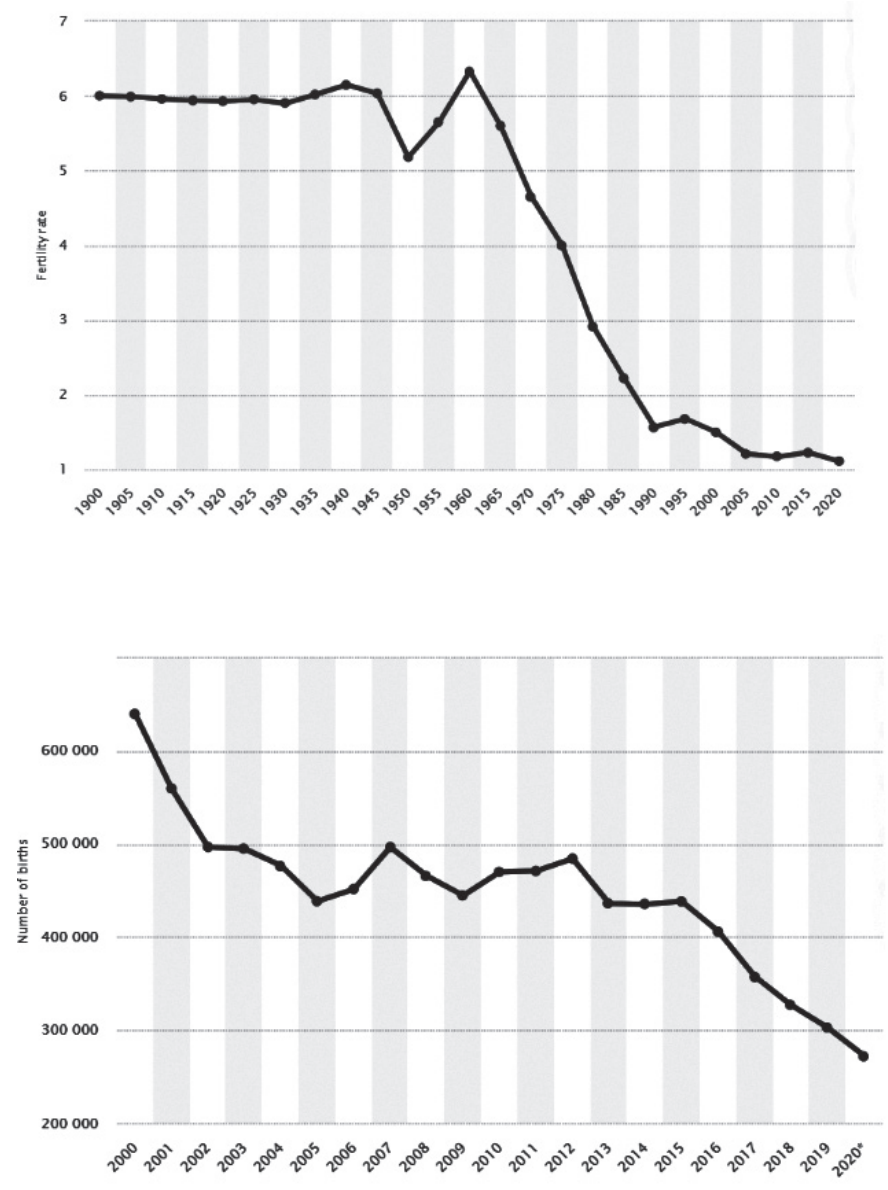

Graph 1. Total Fertility

Rate from

1900 to 2020

Source: Statista. Retrieved from: www.statista.com
Grap 2. Number of Births from 2000 to 2020

Source: Statista. Retrieved from: www.statista.com

large gap between professionally active women and men - in 2020, the share of men in the labour market increased by $20 \%$ and was $72.6 \%$ (Statistics Korea, 2021).

The statistics that affect the assessment of how effective the Korean government has been also refer to the use of parental, maternity and paternity leave. In 2019 , the number of employees taking maternity leave was 73,306 - it applies to $24 \%$ of the total number of births (H. Kim \& Shin, 2021, p. 371). The percentage of women taking maternity leave is low.

There are three main reasons why taking maternity leave is not so frequent. The first reason is low female employment rates, as many women giving birth are not employed. The second reason is that the coverage of employment insurance 


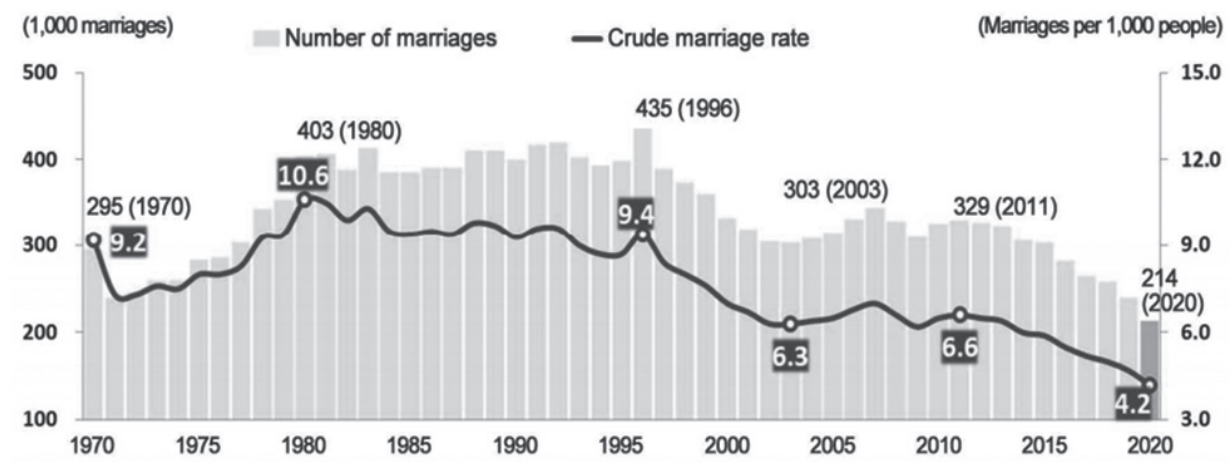

Graph 3. Number of Marriages and Crude Marriage Rate from 1970 to 2020

Source: Statistics Korea. Retrieved from: www.kostat.go.kr.

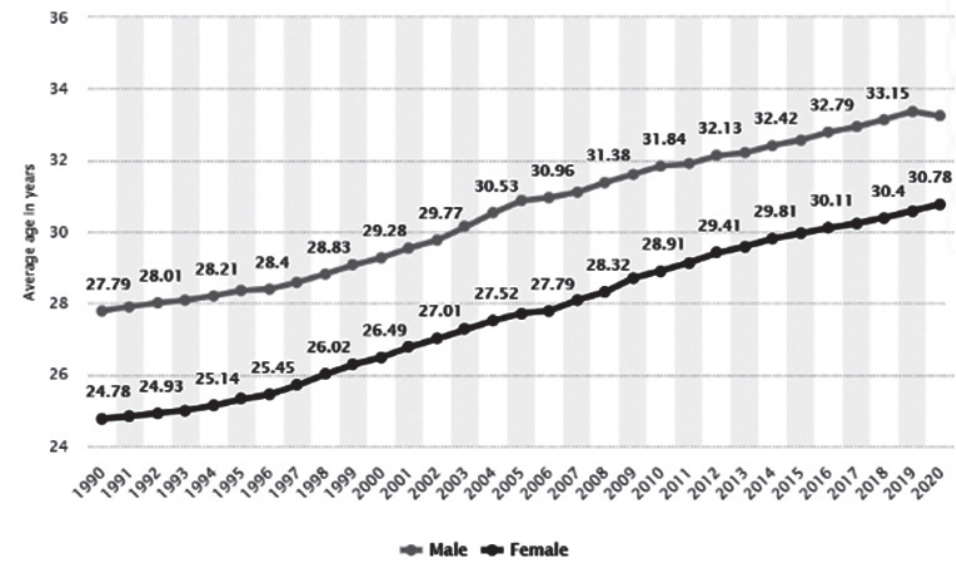

Graph 4. Median Age at First Marriage from 1900 to 2020 , by Gender

Source: Statista.

Retrieved from: www. statista.com

is limited ${ }^{1}$, and the third reason is that self-employed workers are not eligible to maternity leave (H. Kim \& Shin, 2021, p. 371).

In $2019,63.6 \%$ of mothers took parental leave in contrast to only $1.8 \%$ of fathers. While the share of fathers taking parental leave has increased ninefold compared to 2010, still mainly mothers take parental leave. The number of

1 Employment Insurance (EI) does not cover government officials, teachers (both in public and private schools), part-time workers working fewer than 60 hours per month, or domestic workers. EI also does not cover businesses in the agriculture, forestry, fishery, and hunting sectors with four or fewer employees, nor does it cover small construction firms. 
parents taking parental leave has been increasing steadily in recent years. Also noteworthy here is the increase in fathers who have taken parental leave more and more often (L. Yoon, 2021).

Almost 23,000 men in the corporate sector took paternity leave in 2019, which is an increase by $26.2 \%$ compared to 2018 . This was the first time that the male tally has topped 20,000 (Y.J. Kim \& H.J. Kim, 2020). Despite the increase, the number of fathers taking paternity leave is still very low.

The analysis of the above indicators shows that fertility in South Korea is still low. Since 1960, the number of children has been steadily decreasing. The introduction of the family policy to support families with children has only caused small upward fluctuations (see Graphs 1 and 2). The analysis of the contemporary family policy shows that the Korean government keeps introducing new legal regulations, financial support and services to support families with children. However, these actions seem to be insufficient for the contemporary Korean men and women, because the fertility rate has been very low for a long time. The new legal regulations and financial support itself appear to be insufficient in a society in which awareness, the roles of women and men and the social hierarchy have been inspired by the Confucian philosophy for centuries. Changing the awareness of the Korean society towards gender equality in every sphere of life - family, professional and social one - is a difficult challenge which can take decades to meet. It should be pointed out that the gender equality policy was introduced in Korea 20 years ago and it is constantly developing, new legislation is being enacted, and yet South Korea still has the highest gender inequality among OECD countries. According to the analysis of this part of the data, the current family policy is not effective, as it does not increase fertility.

\section{ANALYSIS PART 2 - THE STATISTICAL ANALYSIS OF DATA FROM THE KOREAN LONGITUDINAL SURVEY OF WOMEN AND FAMILIES}

The changes in the number of children the Korean women have or intend to have are important indicators that show fertility trends in South Korea. On their basis, we can also assess how effective the government efforts to increase fert ility in South Korea are. This part of the article presents a statistical analysis of the number of children the respondents have, the number of children living 
together with the respondents, and the fertility intentions in the comparative perspective - in the first wave (2007) and in the seventh wave (2018).

In 2007, all the respondents had children, with the highest percentage being women with two children (54.4\%). Almost $22 \%$ of children did not live together with the respondents. In 2018, nearly $19 \%$ of women did not have children, and the percentage of women with two children decreased by more than 10 percentage points and was $43.9 \%$. The percentage of children not living together increased to almost $43 \%$, which indicates that the percentage doubled between 2007 and 2018. Over the years, there have been changes in the fertility of the respondents. These changes show that the number of children that women have is decreasing and that $20 \%$ of them do not have children at all (Table 1 ).

Table 1. Number of Children and Number of Children Living Together in 2007 and 2018

\begin{tabular}{|c|c|c|c|c|}
\hline \multirow[b]{2}{*}{ Number of children } & \multicolumn{2}{|c|}{$1^{\text {st }}$ Wave 2007} & \multicolumn{2}{|c|}{$7^{\text {th }}$ Wave 2018} \\
\hline & $\mathrm{N}$ & $\%$ & $\mathrm{~N}$ & $\%$ \\
\hline no children & 0.0 & 0.0 & 1703 & 18.5 \\
\hline one child & 1427 & 17.0 & 1221 & 13.2 \\
\hline two children & 4557 & 54.4 & 4055 & 43.9 \\
\hline three children & 1673 & 20.0 & 1613 & 17.5 \\
\hline four children & 501 & 6.0 & 439 & 4.8 \\
\hline five and more & 226 & 2.6 & 198 & 2.1 \\
\hline Total & 8384 & 100.0 & 9229 & 100.0 \\
\hline \multirow{2}{*}{ Number of children living together } & \multicolumn{2}{|c|}{$1^{\text {st }}$ Wave 2007} & \multicolumn{2}{|c|}{$7^{\text {th }}$ Wave 2018} \\
\hline & $\mathrm{N}$ & $\%$ & $\mathrm{~N}$ & $\%$ \\
\hline no children & 1804 & 21.5 & 3941 & 42.7 \\
\hline one child & 2288 & 27.3 & 1854 & 20.1 \\
\hline two children & 3537 & 42.2 & 2737 & 29.6 \\
\hline three and more children & 748 & 9.0 & 701 & 7.6 \\
\hline Total & 8377 & 100.0 & 9233 & 100.0 \\
\hline
\end{tabular}

Source: Author's own calculations based on the data from the Korean Longitudinal Survey of Women and Families 2007 and 2018.

The age group is an independent variable that in statistical terms significantly affects the number of children who live together in both periods covered by the survey (2007: $X 2=381.583 ; \mathrm{p}<0.001 ; 2018: X 2=1845.788 ; \mathrm{p}<0.000)$. While 
the Cramér's V coefficient defines the result from 2007 at the level of a weak relationship ( $\mathrm{V}=0.164)$, in 2018 the level was moderate $(\mathrm{V}=0.439)$ (Table 2).

In 2007 (Wave 1), the respondents most frequently had two children (59.7\%) and one in four of the respondents had one child (24.2\%). Approximately $13 \%$ of women had 3 or more children. The lowest percentage applied to the respondents who did not have children living together. In most cases, women of lower age groups had one child, while women of higher age groups had two children, which is a natural phenomenon (Table 2).

In 2018 (Wave 7), the number of women without children living together increased from $3.1 \%$ in 2007 to $39.6 \%$. The percentage of women with one child decreased by 10 percentage points $(13.0 \%)$ and by nearly 20 percentage points in the case of women with two children (36.2\%) living together. Women in age groups from 34 to 38 and from 39 to 45 most often had two children $(42.6 \%$ and $57.8 \%$, respectively) (Table 2 ).

The analysis shows that the fertility trends among the respondents changed in the analysed time horizon between 2007 and 2018. They indicate a shift towards having fewer children regardless of the respondents' age groups.

The next part of the statistical analysis refers to a question in the Korean Longitudinal Survey of Women and Families about the fertility intentions among the Korean women - do they plan to have a child or not? The respondents had three options to choose from: yes, no, and I don't know.

The statistical analysis of the data included in the first wave of surveys carried out in 2007 shows that the independent variable, which is the respondents' age category, affects the fertility intentions among the Korean women significantly in statistical terms $(X 2=592.227 ; \mathrm{p}<0.001)$, while the Cramér's V coefficient defines them at the level of a weak relationship $(\mathrm{V}=0.265)$. A vast majority of the respondents did not plan to have children (82.9\%). Only $12.1 \%$ of the surveyed Korean women wanted to become mothers, while $5.0 \%$ were not decided yet. In the group of the respondents planning to have children the greatest percentage was Korean women in the 30-39 age group (7.6\%) (see Table 3). The lack of fertility intentions may result from the fact that in Wave 1 all the surveyed women already had children (see Table 1). 
Table 2. Number of Children Living in the Same Household and Age Group of Women

\begin{tabular}{|c|c|c|c|c|c|c|}
\hline \multicolumn{7}{|c|}{$1^{\text {st }}$ Wave 2007} \\
\hline $\begin{array}{c}\text { Age } \\
\text { category }\end{array}$ & $\begin{array}{c}\text { Number } \\
\text { of } \\
\text { children }\end{array}$ & no children & one child & two children & $\begin{array}{l}\text { three and } \\
\text { more children }\end{array}$ & Total \\
\hline \multirow{2}{*}{$19-23$} & $\mathrm{~N}$ & 1 & 15 & 6 & 0 & 22 \\
\hline & $\%$ & 4.5 & 68.2 & 27.3 & 0.0 & 100.0 \\
\hline \multirow{2}{*}{$24-28$} & $\mathrm{~N}$ & 6 & 158 & 115 & 12 & 291 \\
\hline & $\%$ & 2.1 & 54.3 & 39.5 & 4.1 & 100.0 \\
\hline \multirow{2}{*}{$29-33$} & $\mathrm{~N}$ & 15 & 359 & 565 & 83 & 1022 \\
\hline & $\%$ & 1.5 & 35.1 & 55.3 & 8.1 & 100.0 \\
\hline \multirow{2}{*}{$34-38$} & $\mathrm{~N}$ & 24 & 274 & 1042 & 240 & 1580 \\
\hline & $\%$ & 1.5 & 17.3 & 65.9 & 15.2 & 100.0 \\
\hline \multirow{2}{*}{$39-45$} & $\mathrm{~N}$ & 102 & 335 & 1086 & 277 & 1800 \\
\hline & $\%$ & 5.7 & 18.6 & 60.3 & 15.4 & 100.0 \\
\hline \multirow{2}{*}{ Total } & $\mathrm{N}$ & 148 & 148 & 1141 & 2814 & 1415 \\
\hline & $\%$ & 3.1 & 24.2 & 59.7 & 13.0 & 100.0 \\
\hline \multicolumn{7}{|c|}{$7^{\text {th }}$ Wave 2018} \\
\hline $\begin{array}{c}\text { Age } \\
\text { category }\end{array}$ & $\begin{array}{c}\text { Number } \\
\text { of } \\
\text { children }\end{array}$ & no children & one child & two children & $\begin{array}{l}\text { three and } \\
\text { more children }\end{array}$ & Total \\
\hline \multirow[t]{2}{*}{$19-23$} & $\mathrm{~N}$ & 315 & 1 & 0 & 0 & 316 \\
\hline & $\%$ & 99.7 & 0.3 & 0.0 & 0.0 & 100.0 \\
\hline \multirow[t]{2}{*}{$24-28$} & $\mathrm{~N}$ & 441 & 10 & 10 & 1 & 462 \\
\hline & $\%$ & 95.5 & 2.2 & 2.2 & 0.2 & 100.0 \\
\hline \multirow[t]{2}{*}{$29-33$} & $\mathrm{~N}$ & 227 & 72 & 70 & 14 & 383 \\
\hline & $\%$ & 59.3 & 18.8 & 18.3 & 3.7 & 100.0 \\
\hline \multirow[t]{2}{*}{$34-38$} & $\mathrm{~N}$ & 148 & 127 & 239 & 74 & 588 \\
\hline & $\%$ & 25.2 & 21.6 & 40.6 & 12.6 & 100.0 \\
\hline \multirow[t]{2}{*}{ 39-45 } & $\mathrm{N}$ & 135 & 205 & 837 & 271 & 1448 \\
\hline & $\%$ & 9.3 & 14.2 & 57.8 & 18.7 & 100.0 \\
\hline \multirow{2}{*}{ Total } & $\mathrm{N}$ & 1266 & 415 & 1156 & 360 & 3197 \\
\hline & $\%$ & 39.6 & 13.0 & 36.2 & 11.3 & 100.0 \\
\hline
\end{tabular}

Source: Author's own calculations based on the data from the Korean Longitudinal Survey of Women and Families 2007 and 2018. 
The statistical analysis of the data coming from the seventh wave of surveys carried out in 2018 also shows that the independent variable being the age category of the respondents affects the fertility intentions among the Korean women significantly in statistical terms $(X 2=198.016 ; \mathrm{p}<0.001)$, while the Cramér's $\mathrm{V}$ coefficient defines them at the level of a weak relationship $(\mathrm{V}=0.224)$. The percentage of women who plan to become mothers remained at the comparable level of about $4 \%$ - in this group the most women with procreative plans was in the 30-39 age group. The percentage of undecided women increased slightly from $5.0 \%$ to $6.2 \%$ (see Table 3 ).

Table 3. Fertility Intentions by Korean Women

\begin{tabular}{|c|c|c|c|c|c|}
\hline \multicolumn{6}{|c|}{$1^{\text {st }}$ Wave (2007) } \\
\hline \multirow{2}{*}{\multicolumn{2}{|c|}{ Age group }} & \multicolumn{4}{|c|}{ Plan to have a baby or not } \\
\hline & & Yes & No & I don't know & Total \\
\hline \multirow{2}{*}{$19-29$} & $\mathrm{~N}$ & 184 & 202 & 49 & 435 \\
\hline & $\%$ & $4.4 \%$ & $4.8 \%$ & $1.2 \%$ & $10.3 \%$ \\
\hline \multirow{2}{*}{$30-39$} & $\mathrm{~N}$ & 320 & 2307 & 149 & 2776 \\
\hline & $\%$ & $7.6 \%$ & $54.6 \%$ & $3.5 \%$ & $65.7 \%$ \\
\hline \multirow{2}{*}{$40-45$} & $\mathrm{~N}$ & 9 & 991 & 13 & 1013 \\
\hline & $\%$ & $0.2 \%$ & $23.5 \%$ & $0.3 \%$ & $24.0 \%$ \\
\hline \multirow{2}{*}{ Total } & $\mathrm{N}$ & 513 & 3500 & 211 & 4224 \\
\hline & $\%$ & $12.1 \%$ & $82.9 \%$ & $5.0 \%$ & $100.0 \%$ \\
\hline \multicolumn{6}{|c|}{$7^{\text {th }}$ Wave (2018) } \\
\hline \multirow{2}{*}{\multicolumn{2}{|c|}{ Age group }} & \multicolumn{4}{|c|}{ Plan to have a baby or not } \\
\hline & & Yes & No & I don't know & Total \\
\hline \multirow[t]{2}{*}{$19-29$} & $\mathrm{~N}$ & 8 & 19 & 8 & 35 \\
\hline & $\%$ & $0.4 \%$ & $1.0 \%$ & $0.4 \%$ & $1.8 \%$ \\
\hline \multirow[t]{2}{*}{$30-39$} & $\mathrm{~N}$ & 72 & 613 & 86 & 771 \\
\hline & $\%$ & $3.7 \%$ & $31.2 \%$ & $4.4 \%$ & $39.2 \%$ \\
\hline \multirow{2}{*}{$40-45$} & $\mathrm{~N}$ & 8 & 1125 & 28 & 1161 \\
\hline & $\%$ & $0.4 \%$ & $57.2 \%$ & $1.4 \%$ & $59.0 \%$ \\
\hline \multirow{2}{*}{ Total } & $\mathrm{N}$ & 88 & 1757 & 122 & 1967 \\
\hline & $\%$ & $4.5 \%$ & $89.3 \%$ & $6.2 \%$ & $100.0 \%$ \\
\hline
\end{tabular}

Source: Author's own calculations based on the data from the Korean Longitudinal Survey of Women and Families 2007 and 2018. 
The statistical analysis of the longitudinal surveys shows an alarming phenomenon of no fertility intentions. The independent variable being the age category of the respondents affects the fertility intentions among women significantly in statistical terms in two waves of the Korean Longitudinal Survey of Women and Families.

The analysis shows differences in the fertility intentions among the respondents when comparing 2007 to 2018. A large percentage of the respondents did not plan to have children in 2007, as the respondents already had them. The situation was different in 2018, where a large proportion of women who had children and those who did not have children did not plan to become mothers again or for the first time, respectively. When analysing the results in the perspective of how effective the contemporary family policy was, it should be concluded that the proposed and implemented family policy did not affect the fertility intentions of the female respondents from KLoWF until 2018. Moreover, it has been observed that an increasing percentage of the female respondents do not intend to have the first or the next child.

\section{CONCLUSION}

Ageing society is a huge social problem and a challenge for the Korean government to create a family policy that will contribute to the natural increase. The number of children has fallen so drastically that it has become a social problem, leading to numerous governmental debates and discussions on drafting policies to support families in order to encourage them to have children, and to introduce new legal regulations and services to support the family life.

The Korean government started to establish explicit family policies in the mid-2000s. These policies mean a symbolic focus shift to family matters in the history of the social policy in South Korea (Chin et al., 2012).

When analysing the actions undertaken by the Korean government, it may be concluded that the government tries to face the social and demographic transformations that are typical of society 5.0 , by undertaking actions aimed at supporting families in various spheres of its functioning.

The long-term effect of financial support may contribute to increased fertility rate among the Korean families due to the current financial support from the government. However, more time is needed to obtain effective results, as the gender imbalance and gender stereotypes based on the Confucian values which 
are observed in South Korea also play a major role and have the influence on low fertility. Being aware of the problem and also with regard to the low birth rate and aging society, the South Korean government is recently trying to get more men to take parental leave.

However, the demographic data keep indicating a low fertility rate, and the statistical analysis of the data from the Korean Longitudinal Survey of Women and Families clearly shows that the surveyed Korean women did not have fertility intentions, which is an alarming predicator for the low fertility rate being maintained in South Korea. The answer given to the question in the article shows that the family policy pursued by the Korean government is not currently effective, as the fertility rate remains low all the time.

Many scholars pointed out that support for women (wives) from husbands and/or grandparents in childcare greatly affects their decision to have the second child (or the first child) rather than the benefits offered in institutional policies (S.Y.Yoon, 2017). Therefore, not only creating a family-friendly policy is important for increasing the number of births but above all the change of social stereotypes about gender.

Generally speaking, creating a family policy in South Korea is extremely difficult, primarily due to the values in the Korean society, rooted in the Confucian philosophy and male-dominated corporate culture (Tan, 2008). These values refer to the role of men and women in the family and in the workplace. A woman should raise children, take care of her husband and the house. In turn, the man should secure the family economically. These values also apply to the great emphasis placed on education, especially for the male sex. On the other hand, male-dominated corporate culture makes it difficult for women to participate in the labour market on an equal footing by receiving less salaries than men in the same positions, and the possibility of promotion to high positions is also limited.

Due to the above reasons, in the times of contemporary changes in the values of Koreans, who are currently oriented towards professional development and education, creating a family policy is a challenge for the state.

We can conclude that the Korean family policy are not sufficient to create a supportive environment for the family in fertility intentions and behaviour, which is reflected in the continued low fertility rate. As Soo-Yeon Yoon argues, many Koreans are not even aware of the rights and benefits supporting parenting (2017, pp. 227-254). Therefore action should be taken to increase the society's awareness regarding the information on the benefits supporting parenting. 
In order to increase the number of births, the Korean government should promote a greater degree of male domestic duties, a greater commitment to taking care and bringing up children in a more prominent way. Relieving a woman of part of her duties resulting from the motherhood and home care could contribute to a decision to have another child.

The cultural change will take time, but in the case of achieving the aim of increasing fertility there is also a need for the additional labour market, education and social policy reform to help the Koreans achieve both work and family balance, and contribute to the rejuvenation of the Korean society. Thus, there is a need for continued research and policy response.

\section{REFERENCES:}

$5^{\text {th }}$ Science and Technology Basic Plan (n.d.). Retrieved November 12, 2020 from: https://www.mext.go.jp/en/policy/science_technology/lawandplan/title01/ detail01/1375311.htm; https://www8.cao.go.jp/cstp/english/society5_0/index.html.

Bogenschneider, K. (2014). Family Policy Matters: How Policymaking Affects Families and What Professionals Can Do ( $3^{\text {rd }}$ Ed.). New York: Routledge.

Chin, M., Lee, J., Lee, S., Son, S., \& Sung, M. (2012). Family Policy in South Korea: Development, Current Status, and Challenges. Journal of Child and Family Studies, 21(1), 53-64. DOI: 10.1007/s10826-011-9480-1.

Cho, N.H. (2006). New Challenges for Low Fertility and Policy Responses in Korea. Paper Prepared for Policy Forum on Low Fertility and Ageing Society in Seoul, September, 13-14. Retrieved from: http://www.neaef.org/public/neaef/files/documents/publications_pdf/young_leaders/4th/Population\%20-\%20Cho\%20Nam\%20Hoon $\% 20$ YLP\%20paper.pdf.

Fleckenstein, T., \& Lee, S.Ch. (2017). The Politics of Investing in Families: Comparing Family Policy Expansion in Japan and South Korea. Social Politics, 24(1), 1-28. DOI: $10.1093 / \mathrm{sp} / \mathrm{jxw} 008$.

Gauthier, A.H. (1996). The State and the Family: A Comparative Analysis of Family Policies in Industrialized Countries. Oxford: Clarendon Press.

Hank, K., \& Steinbach, A. (2019). Families and Their Institutional Contexts: The Role of Family Policies and Legal Regulations. Kölner Zeitschrift für Soziologie und Sozialpsychologie, 71(1), 375-398. DOI: 10.1007/s11577-019-00603-z.

Jung, M., Ko, W., Choi, Y., \& Cho, Y. (2019). Spatial Variations in Fertility of South Korea: A Geographically Weighted Regression Approach. International Journal of Geo-Information, 8(6), 262-277. DOI: 10.3390/ijgi8060262.

Kim, D.S. (2005). Theoretical Explanations of Rapid Fertility Decline in Korea. The Japanese Journal of Population, 3(1), 2-25. 
Kim, H. (2017a). Korea. Country Report. In: International Network on Leave Policies and Research. Retrieved from: http://www.leavenetwork.org/fileadmin/Leavenetwork/Country_notes/2017/Korea.FINAL.24may2017.pdf.

Kim, H. (2017b). Korea Country Note. In: S. Blum, A. Koslowski, \& P. Moss (Eds.). International Review of Leave Policies and Research 2017 (pp. 252-257). Retrieved from: http://www.leavenetwork.org/lp_and_r_reports. DOI: 10.18445/20200915131331-0.

Kim, H.J. (2015). Korea's Work-Life Balance Policies for Sustainable Growth. OECD. Retrieved from: http://www.oecd.org/social/korea-work-life-balance-policies.htm. Kim, S.Y. (2017, February 23). 2016 Saw Lowest Number of Births Ever Recorded in South Korea. Retrieved August 24, 2017 from: http://english.hani.co.kr/arti/english_edition/e_national/783928.html.

Kim, Y.J., \& Kim, H.J. (2020, January 23). Korean Men Taking Paternity Leave Hit Record High in 2019. Pulse. Retrieved from: https://pulsenews.co.kr/view. php? year=2020\&no=78188.

Kim, H., \& Shin, E. (2021). Korea Country Note. In: A. Koslowski, S. Blum, I. Dobrotić, G. Kaufman, \& P. Moss (Eds.). International Review of Leave Policies and Research (pp. 367-375). 17 $7^{\text {th }}$ International Review of Leave Policies and Related Research 2021. DOI: 10.18445/20210817-144100-0.

Lee, D. (2018). The Evolution of Family Policy in South Korea: From Confucian Familism to Neo-Familism. Asian Social Work and Policy Review, 12(1), 46-53. DOI: 10.1111 /aswp.12137.

Lee, S.S. (2009). Low Fertility and Policy Responses in Korea. The Japanese Journal of Population, 7(1), 57-70.

Lee, S., Duvander, A.Z., \& Zarit, S.H. (2016). How Can Family Policies Reconcile Fertility and Women's Employment? Comparisons between South Korea and Sweden. Asian Journal of Women's Studies, 22(3), 269-288. DOI: 10.1080/12259276.2016.1202027.

Lim, S. (2021). Socioeconomic Differentials in Fertility in South Korea. Demographic Research, 44, 941-978. DOI: 10.4054/DemRes.2021.44.39.

Lim, D.H., Ryu, H., \& Jang, Ch.S. (2020). Aging Issues and HRD in South Korea. In: D.H. Lim, S.W. Yoon, \& D. Cho (Eds.). Human Resource Development in South Korea: Theory and Cases (pp. 37-55). Cham, Switzerland: Palgrave Macmillan.

Mätzke, M., \& Ostner, I. (2010). Introduction: Change and Continuity in Recent Family Policies. Journal of European Social Policy, 20(5), 387-398. DOI: $10.1177 / 0958928710380476$.

Ministry of Gender Equity and Family (n.d.). Retrieved from: www.mogef.go.kr. Ministry of Health and Welfare (2015). The Current State of Low Fertility and Aging Population in Korea. Republic of Korea. Retrieved from: www.mohw.go.kr.

OECD (2017, October 26). Parental Leave Systems. OECD - Social Policy Division. Directorate for Employment, Labour and Social Affairs. Retrieved from: https:// www.oecd.org/els/soc/PF2_1_Parental_leave_systems.pdf. 
O'Neill, A. (2021, March 8). Total Fertility Rate of South Korea 1900-2020. Statista. Retrieved from: https://www.statista.com/statistics/1069672/total-fertility-ratesouth-korea-historical/.

Park, S., Lee, T.M., Kim, S.Y., Jung, S.J., \& Khang, S.H. (2008). Korean Longitudinal Survey of Women Family: The Annual and the $1^{\text {st }}$ Descriptive Report. Seoul, Korea: Korean Women's Development Institute.

Poon, L. (2018, August 3). South Korea Is Trying to Boost Its Birth Rate. It's Not Working. Retrieved from: https://www.citylab.com/life/2018/08/south-korea-needs-morebabies/565169/.

Saraceno, C. (2011, December). Family Policies: Concepts, Goals and Instruments. Carlo Alberto Notebooks, 230. Collegio Carlo Alberto.

Statista (2018). Number of Employees on Parental Leave in South Korea from 2008 to 2017, by Gender. Retrieved form: https://www.statista.com/statistics/641944/southkorea-parental-leaveby-gender/.

Statistics Korea (2016). Marriage and Divorce Statistics in 2016. Retrieved from: http:// kostat.go.kr/portal/eng/pressReleases/8/11/index.board.

Statistics Korea (2020a). Preliminary Results of Birth and Death Statistics in 2019. Retrieved from: http://kostat.go.kr/portal/eng/pressReleases/8/1/index.board.

Statistics Korea (2020b). Live Births by Age Group of Mother, Sex and Birth Order. Retrieved from: https://kosis.kr/eng/statisticsList/statisticsListIndex. do?menuId=M_01_01\&vwcd=MT_ETITLE\&parmTabId=M_01_01\#SelectStats BoxDiv.

Statistics Korea (2021). Summary of Economically Active Pop. by Gender. Retrieved from: https://kosis.kr/statHtml/statHtml.do?orgId=101\&tblId=DT_1DA7001S\&c onn_path=I2\&language $=$ en.

Tan, S.K. (2008). Influences of Confucianism on Korean Corporate Culture. Asian Profile, 36(1), 9-20.

The World Bank (n.d.). Fertility Rate, Total (Births per Woman) - Korea, Rep. Retrieved from: http://data.worldbank.org/indicator/SP.DYN.TFRT.IN?end=2014\&location $s=$ KR\&start $=196$.

World Health Organization (2006). Reproductive Health Indicators: Guidelines for Their Generation, Interpretation and Analysis for Global Monitoring. Retrieved from: http://apps.who.int/iris/bitstream/handle/10665/43185/924156315X_eng.pdf;jses sionid $=839194164016$ F06AD35956AFF9FAA983 sequence $=1$.

Yoo, S.H., \& Sobotka, T. (2018). Ultra-Low Fertility in South Korea: The Role of the Tempo Effect. Demographic Research, 38(1), 549-576. DOI: 10.4054/DemRes.2018.38.22.

Yoon, J. (2006, August). Variations in Patterns of Low Fertility in South Korea in 2004: A County Level Analysis. Master's Thesis. the Office of Graduate Studies of Texas A\&M University. Retrieved from: https://oaktrust.library.tamu.edu/bitstream/ handle/1969.1/ETD-TAMU-1865/YOON-THESIS.pdf?sequence=1\&isAllowed=y. 
Yoon, S.Y. (2017). The Influence of a Supportive Environment for Families on Women's Fertility Intentions and Behavior in South Korea. Demographic Research, 36, 227-254. DOI: 10.4054/DemRes.2017.36.7.

Yoon, L. (2021, March 16). Parental Leave Use by Fathers and Mothers in South Korea 2010-2019. Retrieved from: https:/www.statista.com/statistics/1221066/southkorea-parental-leave-by-fathers-and-mothers/. 